\title{
HUBUNGAN PERSEPSI DAN PARTISIPASI LANSIA DENGAN TINGKAT PEMANFAATAN POSYANDU
}

\section{THE INTERRELATION AMONG ELDERLY PERCEPTION AND PARTICIPATION AND THE UTILIZATION OF POSYANDU}

\author{
Sartika K Laya ${ }^{1)}$, Sunarto Kadir ${ }^{2)}$, irwan ${ }^{3)}$ \\ Jurusan Kesehatan Masyarakat FOK Universitas Negeri Gorontalo \\ sartikaklaya97@gmail.com
}

\begin{abstract}
ABSTRAK
Lansia adalah bagian dari suatu kelompok yang juga membutuhkan pelayanan kesehatan dari pemerintah, oleh karena itu pemerintah membuat program pelayanan untuk lansia yaitu berupa posyandu lansia. Rumusan masalah dalam penelitian ini adalah apakah terdapat hubungan antara persepsi dan partisipasi dengan tingkat pemanfaatan posyandu lansia. Tujuan penelitian untuk mengetahui hubungan persepsi dan parstisipasi dengan tingkat pemanfaatan posyandu lansia.

Metode Penelitian ini adalah penelitian analisis kuantitatif pendekatan cross sectional. Populasi dalam penelitian ini sebanyak 333 lansia dan sampel dalam penelitian ini berjumlah 152 lansia yang ada di kelurahan Limba U I. Teknik analisis data yang digunakan dalam penelitian ini menggunakan uji $C h i$ Square.

Hasil penelitian menunjukkan bahwa ada hubungan persepsi lansia dengan pemanfaatan posyandu lansia $P$-Value $0,000<(0.05)$., dan ada hubungan partisipasi lansia dengan pemanfaatan posyandu lansia $P$-Value $0,000<(0.05)$. Disarankan dukungan keluarga untuk mengoptimalkan persepsi lansia serta partisipasi baik dari lansia dalam mengunjungi posyandu lansia, dukungan dari keluarga bagi lansia dapat dilakukan dengan memberikan perhatian, motivasi, kepedulian terhadap keluhan lansia, sehingga lansia dapat mencurahkan perasaannya dan mendorong untuk lebih aktif dalam mengikuti kegiatan posyandu lansia.
\end{abstract}

Kata kunci : Pemanfaatan, Posyandu Lansia

\begin{abstract}
The elderly are part of a group that also needs health care from the government. Therefore the government created a care program for elderly in the form of an elderly posyandu. This research is aimed at exploring the interrelation among perception and participation and the utilization of center for pre- and postnatal health care and information for elderly. It is generated from the problem statement of research.

This quantitative analitic research employed a cross-sectional study approach.Among 333 elderlies (the research population) in Limba U I sub-district, 152 of them were selected as the sample. The data were analyzed using Chi-Square test.

The result signifies that perception and participation correlate with the utilization of Posyandu for elderly with the P-Value $0.000<(0.05)$ (this applies for both perception and participation variable). This research suggests an optimization in terms of the family support through giving more attention to the elderly. Such an effort also functions to encourage the elderly to visit Posyandu.
\end{abstract}

Keywords: Utilization, Posyandu for Elderly 


\section{LATAR BELAKANG}

Lansia merupakan suatu kelompok penduduk yang cukup rentan terhadap masalah baik masalah ekonomi, sosial, budaya, kesehatan maupun psikologis yang menyebabkan lansia menjadi kurang mandiri dan tidak sedikit lansia yang membutuhkan bantuan orang lain untuk melakukan aktivitas sehari-hari. Lansia sebagai penduduk yang semakin meningkat harapan hidupnya mempunyai berbagai masalah yang akan muncul, salah satunya dalam penanganan kesehatan (Beratanegara, 2012), Lansia umumnya mengalami berbagai penyakit degeneratif akibat terjadinya penurunan fungsi biologis, psikologis, sosial, dan ekonomi. Perubahan ini akan memberikan pengaruh pada seluruh aspek kehidupan, termasuk kesehatannya.

Menurut Undang-undang Nomor 13 tahun 1998 tentang Kesejahteraan Lanjut Usia, yang dimaksud dengan Lanjut Usia adalah penduduk yang telah mencapai usia 60 tahun keatas (Efendi, 2009). Pada hakekatnya menjadi tua merupakan proses alamiah, yang berarti seseorang telah melalui tiga tahap kehidupannya yaitu anak, dewasa dan tua. Memasuki masa tua berarti individu mengalami penurunan secara fisik, mental serta perubahan psikososial (Nugroho, 2008 dalam Purnawati, 2014).

Menurut World Health Organization (WHO) pada tahun 2010 presentase Lansia di dunia diperkirakan mencapai 9,11\% dari jumlah penduduk dunia, serta penduduk lansia di Indonesia pada tahun 2020 mendatang sudah mencapai angka $11,34 \%$ atau tercatat 28,8 juta jiwa, balitanya tinggal $6,9 \%$ yang menyebabkan jumlah penduduk lansia terbesar di dunia (WHO 2010 dalam Noviana, 2014).

Pada kurun waktu 10 tahun terakhir terjadi peningkatan populasi lansia di Indonesia. Hal ini meningkatkan besarnya permasalahan lansia khususnya masalah gizi dan kesehatan karena terjadi peningkatan penyakit degeneratif utamanya penyakit jantung koroner, hipertensi, diabetes mellitus. Upaya untuk mengatasi masalah kesehatan pada lansia maka perlu adanya suatu pelayanan lansia. Pelayanan lansia meliputi pelayanan yang berbasiskan pada keluarga, masyarakat, dan lembaga (Demartoto, 2007).

Pelayanan kesejahteraan sosial bagi

warga lansia di Indonesia boleh dikatakan pelayanannya belum maksimal dibanding Negara maju, misalnya Amerika dan Australia, Indonesia sangat tertinggal dalam hal pemberian kesejahteraan bagi lansia ini (Martono, 2009). Pelayanan sosial lanjut usia (lansia) adalah proses pemberian bantuan yang dilaksanakan secara terencana dan berkelanjutan untuk memenuhi kebutuhan lanjut usia, sehingga yang bersangkutan mampu melaksanakan fungsi sosialnya, salah satu bentuk pelayanan sosial lanjut usia yaitu posyandu lansia (Depkes, 2007).

Berdasarkan data yang diperoleh dari Dinas Kesehatan Kota Gorontalo tahun 2015, Puskesmas Kota Selatan merupakan salah satu dari 10 puskesmas yang berada di Kota Gorontalo yang memiliki jumlah lansia yang banyak yaitu sebanyak 935 jiwa dengan jumlah lansia laki-laki sebanyak 461 jiwa $(49,30 \%)$ dan lansia wanita sebanyak 474 jiwa $(50,69 \%)$ yang mendapat pelayanan kesehatan, Pada data tahun 2016 jumlah lansia mengalami peningkatan yaitu sebanyak 2.245 jiwa dengan jumlah lansia laki-laki sebanyak 828 jiwa $(31,13 \%)$ dan jumlah lansia wanita sebanyak 1.831 jiwa $(68,86 \%)$ yang mendapat pelayanan kesehatan. Sedangkan pada tahun 2017 diperoleh jumlah lansia sebanyak 2116 jiwa dan lansia yang mendapat pelayanan kesehatan hanya 995 lansia dengan jumlah lansia laki-laki sebanyak 332 jiwa $(38,2 \%)$ dan jumlah lansia wanita sebanyak 663 jiwa $(53,2 \%)$ (Data Dinas Kesehatan Kota Gorontalo, 2017).

Namun fenomena di lapangan menunjukkan fakta yang berbeda, berdasarkan wawancara dengan bagian pelayanan kesehatan lansia Posyandu Lansia ternyata hanya ramai pada awal 
pendirian saja, selanjutnya lansia yang memanfaatkan posyandu semakin berkurang. Selain itu lansia hanya akan berkunjung pada posyandu jika diberi obat maupun makanan oleh kader posyandu. Hal ini menunjukkan bahwa kecenderungan pemanfaatan pelayanan kesehatan di posyandu lansia sangat minim, dan keaktifan lansia dalam mengikuti kegiatan posyandu pun juga sangat rendah.

Berdasarkan data kunjungan lansia pada posyandu dilihat berdasarkan kunjungan pada tiap kelurahannya dari bulan Juli hingga September 2017 belum memenuhi sasaran dalam program posyandu lansia yaitu Kelurahan Limba U I dengan jumlah sebanyak

66 kunjungan dari 333 sasaran lansia dan merupakan kunjungan terendah yang belum memenuhi sasaran, Kelurahan Limba U II dengan jumlah sebanyak 131 kunjungan dari 447 sasaran lansia, Kelurahan Limba B dengan jumlah sebanyak 114 kunjungan dari 475 sasaran lansia, Kelurahan Biawao dengan jumlah sebanyak 47 dari 168 sasaran lansia dan Kelurahan Biawu dengan jumlah kunjungan sebanyak 142 kunjungan dari 282 sasaran lansia (Data Puskesmas Kota Selatan, 2017).

Berdasarkan wawancara terhadap 8 orang lansia 3 orang diantaranya yang aktif dalam mengikuti posyandu mengatakan bahwa tidak ada kegiatan tambahan selain timbang berat badan, cek tekanan darah, cek gula darah dan pemberian vitamin, sehingga kegiatan Posyandu Lansia terkesan membosankan bagi para lansia, lansia cenderung datang ke Posyandu Lansia jika ada keluhan fisik saja, dan 5 di antaranya mengatakan mereka tidak aktif dalam mengikuti posyandu karena jarak rumah yang jauh, serta kurangnya informasi tentang kegiatan posyandu di rumah kader. Namun masalah yang selama ini masih terjadi terkait pelaksanaan posyandu lansia adalah lansia belum mengerti sepenuhnya tentang manfaat posyandu lansia, biasanya mereka malas mendatangi posyandu yang diadakan setiap bulan, lansia datang ke Posyandu Lansia jika ada keluhan fisik saja, jika tidak ada keluhan fisik para lansia lebih memilih dirumah karena merasa bosan dengan kegiatan Posyandu Lansia yang tidak ada variasi kegitan lainnya seperti senam lansia, jalan sehat, maupun pendidikan kesehatan bagi lansia.

Berdasarkan uraian di atas Posyandu lansia dapat menimbulkan salah persepsi yang akhirnya kunjungan lansia ke posyandu akan rendah, bila pengetahuan lebih dapat dipahami, maka timbul suatu sikap dan perilaku untuk berpartisipasi. Lansia yang tidak aktif dalam memanfaatkan pelayanan kesehatan di posyandu lansia, maka kondisi kesehatan mereka tidak dapat terpantau dengan baik, sehingga apabila mengalami suatu resiko penyakit akibat penurunan kondisi tubuh dan proses penuaan dikhawatirkan dapat berakibat fatal dan mengancam jiwa mereka (Komnas Lansia, 2010).

Berdasarkan uraian latar belakang masalah, maka penulis tertarik untuk melakukan penelitian dengan judul

"Hubungan Persepsi dan Partisipasi Lansia dengan Tingkat Pemanfaatan (Utilization) Posyandu"

\section{METODE PENELITIAN}

Metode yang di gunakan dalam penelitian adalah analisis kuantitatif dengan pendekatan cross sectional study menggunakan uji Chi Square. Tujuan Penelitian Untuk mengetahui hubungan persepsi dan partisipasi lansia dengan tingkat pemanfaatan (utilization) posyandu Penelitian ini di lakukan di Kelurahan Limba U I pada Pada lansia umur 60-69 tahun. Waktu penelitian dilaksankaan selama 2 bulan.

Populasi pada penelitian ini adalah seluruh lansia yang berumur (60 sampai 69 tahun) yang tinggal di kelurahan Limba U I yaitu sebanyak 333 orang. Sampel dalam penelitian ini sebanyak 152 orang. Sampel dalam penelitian ini menggunakan teknik Purposive sampling yaitu suatu cara 
pengambilan sampel yang digunakan dengan pertimbangan tertentu (Sugiyono, 2010).

Analisis data dilakukan untuk mengetahui distribusi masing-masing variable yang $d$ teliti. Selanjutnya data yang di tampilkan dalam bentuk narasi

Analisis bivariat merupakan analisi hasil dari variable bebas yang di duga mempengaruhi variable terikat. Untuk menguji hipotesis di lakukan analisa satatistik uji chi-square pada tingkat kemaknaan 95\% (P \0,05) yang di olah menggunakan program SPSS.

\section{HASIL}

Berdasarkan ahsil penelitian diketahui distribusi sampel berdarasakan kelompom umur dilihat pada table berikut ;

Tabel 1. Distribusi Sampel Berdasarkan Kelompok Umur Lansia

\begin{tabular}{|l|l|l|}
\hline Umur & Frekuensi & $\%$ \\
\hline $\begin{array}{l}56-65 \text { Tahun } \\
\text { (Lansia Akhir) }\end{array}$ & 121 & 79,6 \\
\hline$>65$ Tahun Manula & 31 & 20,4 \\
\hline Total & 152 & 100,0 \\
\hline
\end{tabular}

Sumber : Data Primer, 2018

Berdasarkan data pada tabel diatas diketahui bahwa lansia yang menjadi responden sebagian besar berumur antara 5665 tahun yang berjumlah 121 orang $(79,6 \%)$, sedangkan paling sedikit pada umur $>65$ tahun berjumlah 31 orang $(20,4 \%)$.

Tabel 2 Distribusi Sampel Berdasarkan Jenis kelamin Lansia

\begin{tabular}{|l|l|l|}
\hline Jenis Kelamin & Frekuensi & $\%$ \\
\hline Laki-laki & 6 & 3,9 \\
\hline Perempuan & 146 & 96,1 \\
\hline Total & 152 & 100,0 \\
\hline
\end{tabular}

Sumber : Data Primer, 2018

Berdasarkan data pada table di atas dapat dijelaskan bahwa lansia yang berjenis kelamin laki-laki sebanyak 6 orang atau sebesar 3,9\% sedangkan yang perempuan sebanyak 146 orang atua sebesar $96,1 \%$.

Tabel .3 Distribusi sampel
Berdasarkan pendidikan Lansia

\begin{tabular}{rll}
\hline Pendidikan & Frekuensi & $\%$ \\
\hline SD/Sederajat & 122 & $\mathbf{8 0 , 3}$ \\
SMP/Sederaja & 29 & $\mathbf{1 9 , 1}$ \\
$\mathbf{t}$ & & \\
SMA/Sederaja & 1 & $\mathbf{0 , 7}$ \\
$\mathbf{t}$ & & \\
\hline Total & $\mathbf{1 5 2}$ & $\mathbf{1 0 0 , 0}$ \\
\hline
\end{tabular}

Sumber : Data Primer, 2018

Berdasarkan data pada diatas diketahui bahwa sebagian besar lansia yang menjadi responden memiliki tingkat pendidikan $\mathrm{SD} /$ sederajat yakni sebanyak 122 orang atau sebesar $80,3 \%$ sedangkan yang

paling kecil frekuensinya yakni SMA/sederajat yakni sebanyak 1 orang atau sebesar $0,7 \%$.

Tabel 4. Distribusi sampel

Berdasarkan persepsi lansia

\begin{tabular}{|l|l|l|}
\hline Persepsi & Frekuensi & $\%$ \\
\hline Negatif & 111 & 73.0 \\
\hline Positif & 41 & 27.0 \\
\hline Total & 152 & 100.0 \\
\hline
\end{tabular}

Sumber : Data Primer, 2018

Berdasarkan tabel di atas dapat dilihat bahwa responden yang memiliki persepsi negatif sebanyak 111 orang atau sebesar $73,0 \%$ sementara lansia yang memiliki persepsi positif sebanyak 41 orang atau sebesar $27,0 \%$ dari keseluruhan sampel penelitian.

Tabel 5 Distribusi Sampel

Berdasarkan Partisipasi lansia

\begin{tabular}{|l|l|l|}
\hline Partisipasi & Frekuensi & $\%$ \\
\hline Kurang Aktif & 122 & 80.3 \\
\hline Aktif & 30 & 19.7 \\
\hline Total & 152 & 100.0 \\
\hline
\end{tabular}

Sumber : Data Primer, 2018

Berdasarkan tabel di atas dapat dilihat bahwa responden yang memiliki partisipasi kurang Aktif sebanyak 122 orang atau sebesar $80,3 \%$ sementara lansia yang memiliki partisipasi aktif sebanyak 30 orang atau sebesar 19,7\% dari keseluruhan sampel penelitian.

Tabel 6 Distribusi sampel berdasarkan tingkat pemanfaatan posyandu Lansia

\begin{tabular}{l|l|l}
\hline $\begin{array}{l}\text { Tingkat } \\
\text { Pemanfaat } \\
\text { an }\end{array}$ & Frekuensi & $\%$ \\
\hline Rendah & 118 & $\mathbf{7 7 . 6}$ \\
\hline Tinggi & 34 & $\mathbf{2 2 . 4}$ \\
\hline Total & $\mathbf{1 5 2}$ & $\mathbf{1 0 0 . 0}$ \\
\hline
\end{tabular}


Sumber : Data Primer, 2018

Berdasarkan data pada tabel diatas dijelaskan bahwa responden yang memanfaatkan Posyandu Lansia sebanyak 34 orang atau sebesar $22,4 \%$ sementara lansia yang tidak memanfaatan Posyandu Lansia sebanyak 118 orang atau sebesar 77,6\% dari keseluruhan sampel penelitian.

Tabel 7 Hubungan Persepsi Lansia dengan Pemanfaatan (Utilization) Posyandu

\begin{tabular}{|c|c|c|c|c|}
\hline \multirow{2}{*}{$\begin{array}{c}\text { Persep } \\
\text { si }\end{array}$} & \multicolumn{2}{|c|}{$\begin{array}{c}\text { Pemanfaatan } \\
\text { Posyandu }\end{array}$} & \multirow{2}{*}{ Total } & $\begin{array}{c}P- \\
\text { Valu } \\
e\end{array}$ \\
\cline { 2 - 3 } & Tinggi & Rendah & & \multirow{2}{*}{$\begin{array}{c}0,00 \\
0\end{array}$} \\
\hline Positif & 22 & 19 & 41 & 111 \\
\hline $\begin{array}{c}\text { Negati } \\
\mathrm{f}\end{array}$ & 12 & 99 & 152 & \\
\hline Total & 34 & 118 & 152 \\
\hline
\end{tabular}

Sumber : Data Primer, 2018

Berdasarkan tabel diatas dapat diketahui bahwa dari 41 lansia yang memiliki persepsi positif sebanyak 22 lansia yang memiliki persepsi positif dengan pemanfaatan posyandu tinggi dan 19 lansia yang memiliki persepsi positif dengan pemanfaatan posyandu rendah, dan dari 111 lansia yang memiliki pesepsi negatif sebanyak 12 lansia memiliki persepsi negatif dengan pemanfaatan posyandu tinggi,

99 lansia yang memiliki persepsi negatif dengan pemanfaatan posyandu rendah. Setelah di lakukan uji statistik dengan hasil analisis diperoleh nilai Probability Value (P-Value) variabel Persepsi lansia sebesar 0,000. Nilai signifikansi ini masih lebih kecil dibandingkan dengan nilai alpha yang digunakan $(0,05)$ sehingga $\mathrm{H}_{0}$ diterima. Dengan demikian dapat disimpulkan bahwa pada tingkat kepercayaan 95\% terdapat hubungan yang signifikan persepsi lansia dengan pemanfaatan (utilization) posyandu.

Tabel 8 Hubungan Partisipasi Lansia Dengan pemanfaatan (Utilization) Posyandu

\begin{tabular}{|c|c|c|c|c|}
\hline \multirow{2}{*}{$\begin{array}{c}\text { Partisipa } \\
\text { si }\end{array}$} & \multicolumn{2}{|c|}{$\begin{array}{c}\text { Pemanfaatan } \\
\text { Posyandu }\end{array}$} & \multirow[t]{2}{*}{ Total } & \multirow{2}{*}{$\begin{array}{c}P- \\
\text { Valu } \\
e\end{array}$} \\
\hline & $\begin{array}{c}\text { Tingg } \\
\mathrm{i}\end{array}$ & $\begin{array}{c}\text { Renda } \\
\mathrm{h}\end{array}$ & & \\
\hline Aktif & 24 & 6 & 30 & \\
\hline $\begin{array}{c}\text { Kurang } \\
\text { Aktif }\end{array}$ & 10 & 112 & 112 & $\begin{array}{c}0,00 \\
0\end{array}$ \\
\hline
\end{tabular}

\begin{tabular}{c|c|c|c|c|}
\hline Jumlah & 34 & 118 & 152 & \\
\hline
\end{tabular}

Berdasarkan tabel diatas dapat diketahui bahwa dari 30 lansia yang memiliki partisipasi aktif sebanyak 24 lansia memiliki partisipasi aktif dengan pemanfaatan posyandu tinggi dan 6 lansia memiliki partisipasi aktif dengan pemanfaatan posyandu rendah dan 122 lansia yang memiliki partisipasi kurang aktif sebanyak 10 lansia memilki partisipasi kurang aktif dengan pemanfaatan posyandu yang tinggi dan 112 lansia memiliki partisipasi

kurang aktif dengan pemanfaatan posyandu rendah. Setelah di lakukan uji statistik dengan hasil analisis diperoleh nilai Probability Value $(P$-Value $)$ variabel Partisipasi lansia sebesar 0,000 . Nilai signifikansi ini masih lebih kecil dibandingkan dengan nilai alpha yang digunakan $(0,05)$ sehingga $\mathrm{H}_{0}$ diterima. Dengan demikian dapat disimpulkan bahwa pada tingkat kepercayaan $95 \%$ terdapat hubungan yang signifikan partisipasi lansia dengan pemanfaatan (utilization) posyandu.

\section{PEMBAHASAN}

\subsection{Karakteristik Lansia}

\subsubsection{Umur}

Pada kelurahan Limba U I lansia yang saya teliti pada penelitian ini sebanyak 121 lansia dengan persentase $79,6 \%$ yang berusia 56-65 (lansia akhir) dan 31 lansia dengan persentase $20,4 \%$ yang berusia $>65$ tahun (manula), usia yang semakin bertambah membuat lansia tidak bisa aktif dalam kegiatan posyandu lansia kegiatan posyandu lansia.

Menurut Purwadi (2011) bahwa usia yang semakin bertambah membuat lansia tidak bisa aktif dalam kegiatan posyandu lansia. Pertambahan usia akan menimbulkan perubahan-perubahan pada struktur dan fisiologis sehingga menimbulkan kemunduran pada fisik dan psikis lansia. Semakin bertambahnya umur manusia, terjadi proses penuaan secara degeneratif yang akan berdampak pada perubahan-perubahan diri manusia, tidak hanya perubahan fisik, tetapi juga kognitif, perasaan, sosial, dan sexual (Azizah, 2011).

\subsubsection{Jenis Kelamin}

Pada kelurahan Limba U I lansia yang saya teliti pada penelitian ini sebanyak 6 lansia laki-laki dengan persentase $3,9 \%$ dan 146 lansia perempuan dengan persentase $96,1 \%$. 
Dari data yang diperoleh lansia perempuan cenderung mempunyai perilaku yang tinggi untuk mengikuti Posyandu lansia, sebaliknya bagi lansia laki-laki mempunyai perilaku cenderung

sedang dan rendah. Hal ini sejalan dengan pendapat menurut Farun (2009) bahwa perempuan lebih tekun dalam mengikuti Posyandu lansia dan laki-laki tentunya cepat bosan jika dilihat dari segi psikologis jika mengikuti Posyandu lansia.

\subsubsection{Pendidikan}

Pada kelurahan Limba U I lansia yang saya teliti pada penelitian ini sebanyak 122 lansia dengan persentase $80,3 \%$ dengan

pendidikan SD/Sederajat, 29 lansia dengan persentase 19,1 \% dengan pendidikan SMP/Sederajat dan 1 lansia dengan persentase $0,7 \%$ dengan pendidikan SMA/Sederajat, hal ini dikarenakan waktu mereka usia sekolah, sekolah masih jarang dan hanya orang-orang tertentu yang bisa bersekolah.

Menurut Wahono (2010), pendidikan sebagai suatu proses dalam rangkaian mempengaruhi dan dengan demikian akan menimbulkan perubahan perilaku pada dirinya, karena tidak dapat dipungkiri bahwa semakin tinggi pendidikan seseorang semakin mudah pulamereka menerima informasi kesehatan.Sebaliknya jika seseorang yang tingkat pendidikanya rendah, akan menghambat perkembangan seseorang terhadap penerimaan, informasi kesehatan dan nilai-nilai baru yang di perkenalkan.

\subsubsection{Persepsi Lansia}

Pada kelurahan Limba U I lansia yang saya teliti pada penelitian ini sebanyak 111 lansia dengan persentase $73,0 \%$ dengan persepsi negatif, 41 lansia dengan persepsi positif dengan persentase $27,0 \%$, salah satu faktor yang berpengaruh terhadap keikutsertaan lansia dalam posyandu adalah persepsi tentang Posyandu lansia itu sendiri.

Menurut Juniardi (2013) bahwa lansia cenderung memiliki sifat tertutup (negatif) sehingga pendekatan yang perlu diberikan oleh kader kesehatan untuk meningkatkan intensitas kunjungan ke posyandu adalah pendekatan personal. memiliki sifat tertutup sehingga pendekatan yang perlu diberikan oleh kader kesehatan untuk meningkatkan intensitas kunjungan ke posyandu adalah pendekatan personal.

\subsubsection{Partispasi Lansia}

Pada kelurahan Limba U I lansia yang saya teliti pada penelitian ini sebanyak 122 lansia dengan persentase 80,3 \% dengan partisipasi kurang aktif, 30 lansia dengan persentase $19,7 \%$ dengan partisipasi aktif, tingginya persentase responden yang kurang aktif dalam mengikuti posyandu lansia berkemungkinan pada faktor umur , pendidikan, maupun dukungan keluarga.

Dukungan keluarga sangat berperan dalam mendorong minat atau kesediaan lansia untuk mengikuti kegiatan posyandu lansia. Keluarga bisa menjadi motivator kuat bagi lansia apabila selalu menyediakan diri untuk mendampingi atau mengantarkan lansia ke posyandu, mengingatkan lansia jika lupa

jadwal posyandu, dan berusaha membantu mengatasi segala permasalahan bersama lansia (Fahrun, 2009).

\subsubsection{Pemanfaatan Posyandu Lansia}

Pada kelurahan Limba U I lansia yang saya teliti pada penelitian ini sebanyak 118 lansia dengan persentase 77,6 \% tidak memanfaatkan posyandu (rendah), 30 lansia dengan persentase 22,4 \% memanfaatkan posyandu (tinggi), hal ini dikarenakan fasilitas kesehatan yang ada pada posyandu belum memenuhi atau masih terbatas.

Menurut Noviana (2014) bahwa keadaan fasilitas yang memadai akan membantu terhadappenyelenggaraan pelayanan kepada lansia. Fasilitas menjadi salah satupertimbangan konsumen dalam menentukan pilihan. Apabila suatu posyandu mempunyai fasilitas yang memadai sehinggga dapat memudahkan lansia dalam menggunakan fasilitas yang ada dan membuat nyaman para lansia, ketika di posyandu yang memberikan suasana menyenangkan dengan desain fasilitas yang menarik akan mempengaruhi lansia dalam memeriksakan kesehatannya.

Selain fasilitas adapun faktor yang mempengaruhi pemanfaatan posyandu lansia adalah persepsi kualitas pelayanan posyandu. Persepsi lansia terhadap kualitas pelayanan di posyandu lansia meliputi persepsi lansia tentang tenaga kesehatan, kader, pemeriksaan yang dilakukan, waktu tunggu dan kegiatan di posyandu lansia (Purwadi, 2011).

4.1.7 Hubungan persepsi lansia dengan tingkat pemanfaatan (Utilization) Posyandu

Dari hasil yang di peroleh bahwa persepsi lansia memiliki hubungan dengan 
tingkat pemanfaatan posyandu hal ini di lihat hasil pengujian bivariate menunjukan bahwa nilai probability Value ( $P$-Value) sebesar 0,000 , nilai signifikasi ini masih kecil dibandingkan dengan nilai alpha yang di gunakan $(0,05)$ sehingga $\mathrm{H}_{0}$ diterima. Dengan demikian dapat disimpulkan terdapat hubungan yang signifikan antara persepsi dengan tingkat pemanfaatan posyandu (Utilization) di Kelurahan Limba U I.

Berdasarkan tabulasi silang diperoleh 99 lansia memiliki persepsi negatif dengan pemanfaatan posyandu lansia rendah. Alasan lansia tidak mengikuti posyandu lansia yaitu fasilitas posyandu yang kurang memadai, kurangnya kegiatan posyandu seperti senam lansia dan alat pemeriksaan kesehatan yang

sangat kurang sehingga menyebabkan lansia lebih memilih untuk tidak datang ke posyandu lansia.

Hal ini sesuai dengan penelitian Wahono (2010) yang mengatakan bahwa perlu adanya inovasi-inovasi kegiatan atau pelayanan yang berikan oleh petugas kesehatan dan kader posyandu, baik itu pemeriksaan laboratorium sederhana, senam lansia, atau pemberian penyuluhan menggunakan media yang menarik bagi masyarakat. Ketersediaan sarana dan prasarana merupakan salah satu faktor yang berperan dalam perilaku kesehatan, dengan tersedianya peralatan ini akan menunjukkan para lansia untuk datang ke posyandu lansia.

Selain kurangnya kegiatan posyandu persepsi negatif yang muncul pada lansia juga disebabkan oleh pendidikan. Dalam hasil wawancara sebagian besar lansia berpendidikan $\mathrm{SD} /$ sederajat, pendidikan yang kurang/rendah menyebabkan responden kesulitan untuk mencernah informasi tentang posyandu lansia, kesulitan ini ditambah dengan kurangnya keinginan untuk mencari informasi tentang Posyandu lansia baik melalui bertanya kepada saudara, teman, tetangga atau langsung bertanya kepada petugas kesehatan dan keadaan ini yang menyebabkan munculnya persepsi negatif pada lansia.

$\mathrm{Hal}$ ini sejalan dengan penelitian Ayu (2014) yang mengatakan persepsi negatif dipengaruhi oleh pendidikan, pendidikan tidak lepas dari proses belajar, pendidikan adalah sesuatu untuk memperoleh ketrampilan yang dibutuhkan manusia dalam kehidupan dalam menyempurnakan potensi atau kemampuan biologis dan psikis dalam hubungan dunia luar bermasyarakat.

Adapun 12 lansia memanfaatkan posyandu lansia dengan pemanfaatan posyandu yang tinggi karena adanya fasilitas pemeriksaan untuk DM, kolestrol, dan asam urat selain itu mereka takkan mau memanfaatkan posyandu. Begitu juga dengan

19 lansia yang memiliki persepsi positif namun pemanfaatan posyandu yang rendah hal ini di sebakan karena mereka merasa bahwa kodisi fisik mereka masih sehat sehingga mereka jarang memanfaatkan posyandu meskipun mereka tau manfaat yang bisa mereka dapatkan pada kegiatan posyandu lansia.

Selain itu 22 lansia memanfaatkan posyandu dipengaruhi oleh kinerja kader, lansia yang memiliki persepsi baik/ positif tentang peran kader cenderung memiliki frekuensi kunjungan yang tinggi. Sementara itu, responden yang memiliki persepsi yang cukup atau kurang cenderung memiliki frekuensi kunjungan yang rendah.

Hal ini sejalan dengan penelitian Lestari dkk (2011) yang mengatakan bahwa persepsi lansia terhadap kader kesehatan merupakan salah satu faktor yang berperan terhadap keaktifan kunjungan lansia ke posyandu. Disebutkan bahwa lansia yang memiliki persepsi baik terhadap kader memiliki peluang 6,5 kali lebih tinggi untuk aktif berkunjung ke posyandu.

Persepsi yang baik/positif dari lansia akan membuat lansia aktif dalam menggunakan dan memanfaatkan Posyandu Lansia. Sebagaimana hasil tabulasi silang ditemukan bahwa lansia dengan persepsi negatif maka akan rendah tingkat pemanfaatannya hal yang sama juga pada lansia dengan persepsi positif maka akan intens dalam Pemanfaatan Posyandu Lansia oleh lansia di Posyandu Lansia.

Hasil temuan ini sejalan dengan pendapat Pertiwi (2013) bahwa kepuasan pasien merupakan hal yang penting karena kedua hal tersebut mengarah ketingginya kunjungan posyandu lansia kedatangan dan kepatuhan pasien terhadap saran petugas kesehatan. Sehingga persepsi yang positif dari lansia akan mendorong keaktifan dari lansia dimana keaktifan lansia dalam kegiatan posyandu lansia sangat membantu petugas kesehatan dalam memantau kesehatan lansia dan memberikan pengertian tentang pola kehidupan sehat di usia lanjut. Manfaat dari 
keaktifan lansia di posyandu lansia antara lain petugas kesehatan dapat memperoleh datadata yang berkaitan dengan keadaan lansia saat itu, minimal diketahui berat dan tinggi badan, denyut nadi, tekanan darah, keluhan fisik dan penyakit yang diderita.

4.1.8 Hubungan partisipasi lansia dengan tingkat pemanfaatan (Utilization)

Posyandu

Dari hasil yang di peroleh bahwa partisipasi lansia memiliki hubungan dengan tingkat pemanfaatan posyandu hal ini di lihat hasil pengujian bivariate menunjukan bahwa nilai probability Value ( $P$-Value) sebesar 0,000 , nilai signifikasi ini masih kecil dibandingkan dengan nilai alpha yang di

gunakan $(0,05)$ sehingga $\mathrm{H}_{0}$ diterima. Dengan demikian dapat disimpulkan terdapat hubungan yang signifikan antara partisipasi dengan tingkat pemanfaatan (Utilization) posyandu di Kelurahan Limba U I.

Berdasarkan tabulasi silang diperoleh

112 lansia memiliki partisipasi kurang aktif dengan pemanfaatan posyandu lansia rendah, partisipasi kurang aktif dapat menyebabkan lansia menjadi malas mengikuti kegiatan posyandu. Hal ini disebabkan oleh beberapa faktor seperti umur lansia yang rentan akan penyakit, selain itu kondisi fisik lanjut usia yang terkadang tidak dapat memungkinkan untuk ikut serta dalam Posyandu Lansia dan juga belum lengkapnya peralatan kesehatan untuk mengecek kesehatan lanjut usia.

Hasil ini sesuai dengan temuan dari Wahyuni (2003) bahwa Partisipasi lansia dalam kegiatan pembinaan kesehatan dipengaruhi oleh umur, jenis kelamin, pekerjaan, sikap, kebutuhan, dan dukungan keluarga. Diharapkan kepada pihak terkait agar dapat melakukan berbagai upaya untuk meningkatkan partisipasi lansia dalam kegiatan pembinaan kesehatan antara lain melalui promosi dan penyuluhan kesehatan tentang manfaat kegiatan pembinaan kesehatan lansia.

Adapun 10 lansia dengan partisipasi kurang aktif namun dengan pemanfaatan posyandu tinggi dikarenakan mereka hanya akan datang jika posyandu mengadakan kegiatan lain selain pemeriksaan ataupun mereka akan datang jika ada pembagian resep obat/vitamin, begitu juga 6 lansia dengan partisipasi aktif dengan pemanfaatan posyandu rendah dikarenakan lansia akan mengikuti kegiatan apabila tidak mengalami kendala seperti sibuk ataupun sedang sakit.

Selain itu partisipasi lansia dalam memanfaatkan 24 lansia memiliki partisipasi aktif dengan pemanfaatan posyandu yang tinggi hal ini disebabkan karena dukungan keluarga yang menemani lansia untuk mengunjungi posyandu. Hal ini sejalan dengan penelitian Sundari (2013) yaitu tentang hubungan support system keluarga dalam meningkatkan gairah hidup lansia, yang menunjukkan bahwa support system dari keluarga ada hubungannya dalam meningkatkan gairah hidup lansia.

\section{SIMPULAN DAN SARAN}

\subsection{Simpulan}

Berdasarkan hasil penelitian dan pembahasan pada bab sebelumnya dapat disimpulkan bahwa Terdapat hubungan yang signifikan antara persepsi dengan tingkat pemanfaatan (Utilization) posyandu dengan nilai $P$ - Value $0,000<\alpha(0,05)$. Terdapat hubungan yang signifikan antara partisipasi dengan tingkat pemanfaatan (Utilization) posyandu dengan nilai $P$ - Value $0,000<\alpha$ $(0,05)$.

4.1.2 Saran

Perlunya dukungan keluarga untuk mengoptimalkan partisipasi lansia serta persepsi baik dari lansia dalam mengunjungi posyandu lansia. Dukungan dari keluarga bagi lansia dapat dilakukan dengan memberikan perhatian, motivasi, kepedulian terhadap keluhan lansia, sehingga lansia dapat mencurahkan perasaannya dan mendorong untuk lebih aktif dalam mengikuti kegiatan posyandu lansia.

\section{REFERENSI}

1. Ayu, I. 2014. Persepsi Lansia Tentang Posyandu Lansia Di Posyandu Lansia "Hasrat" Kelurahan Gedongan Kota Mojokerto.

2. Azizah, L. 2011. Keperawatan Lanjut Usia, Edisi 1. Graha Ilmu : Yogyakarta

3. Bratanegara, A. 2012. Gambaran Dukungan Keluarga Terhadap Pemanfaatan Posbindu Lansia Di Kelurahan Karasak Kota Bandung. Students E- Journal

4. Demartoto,A. 2007. Pelayanan Sosial Non Panti Bagi Lansia Suatu Kajian Sosiologis. Surakarta: Sebelas Maret University press.

5. Depkes RI. 2007. Profil Kesehatan Indonesia, Jakarta: JNPK-KR

6. Efendi. 2009. Keperawatan Kesehatan 
Komunitas. Salemba Medika : Jakarta

7. Fahrun, N. 2009. Faktor-Faktor Yang Mempengaruhi Kunjungan Lansia Ke Posyandu Lansia Di Rw Vii Kelurahan Wonokusumo Kecamatan Semampir Surabaya. Jurnal : Surabaya Fakultas IlmuKesehatan. UMSurabaya

8. Juniardi, F. 2013. Faktor-faktor yang Mempengaruhi Rendahnya Kunjungan Lansia ke Posyandu Lansia di Puskesmas Batang Beruh Kecamatan Sidikalang Kabupaten Dairi. Welfare State 2(1): 1-7

9. Komnas Lansia. 2010. Pedoman Pelaksanaan Posyandu Lanjut Usia. Jakarta

10. Lestari, dkk.(2011). Beberapa Faktor yang Berperan Terhadap Keaktifan Kunjungan Lansia ke Posyandu: Studi Surakarta Kasus di Desa Tamantirto

11. Noviana, E.2014. FaktorFaktorYang Berhubungan DenganKunjungan Lansia Ke Posyandu Lansia Di Desa Ngempon KecamatanBergas Kabupaten Semarang. Program Studi Diploma IV Kebidanan. Karya ilmiah. Stikes Ngudi Waluyo Ungaran.Semarang. Diakses dari (http://perpusnwu.web.id/karyailmiah/d ocuments/3645.pdf.) tanggal 21 November 2017

12. Pertiwi, H.W. 2013. Faktor-Faktor yang Berhubungan denganFrekuensi Kehadiran Lanjut Usia di Posyandu Lansia. Bidan Prada : Jurnal Ilmiah Kebidanan, Vol . 4 No. 1 Edisi Juni 2013

13. Pujiono. 2009. Faktor-faktor yang Berhubungan dengan Pemanfaatan Posyandu Lansia di Desa Jetis Kecamatan Karangrayung Kabupaten Grobogan. . Tesis. Semarang: Program Studi Magister Promosi Kesehatan Program Pascasarjana Universitas Diponegoro.

14. Purwadi, H. 2011. Faktor-Faktor Yang Mempengaruhi Pemanfaatan Posyandu Lansia Di Dusun Karangkulon Desa Wukirsari Kecamatan Imogiri Kabupaten Bantul. Yogyakrta: Stikes Alma Ata Yogyakarta Jurusan Keperawatan;

15. Sundari, dkk. 2013. Faktor-Faktor Penyebab Rendahnya Keaktifan Posyandu Lansia. Skripsi. Politeknik Kesehatan Denpasar

16. Wahyuni. 2003. Kajian terhadap Kesejahteraan Penduduk Lanjut Usia di
Pedesaan. Laporan Riset Unggulan Terpadu VIII Bidang Dinamika Sosial, Ekonomi, dan Budaya. IPB, Bogor.

17. Wahono, H. 2010. Analisis Faktor-Faktor yang Mempengaruhi Pemanfaatan Posyandu Lansia Di Gantungan Makamhaji . Skripsi. Surakarta: Fakultas Ilmu Kesehatan. Universitas Muhammdiyah Surakarta 